\title{
Cum se vede situația actuală a ultrasonografiei din capitala României.
}

În București, ca în oricare oraș din România și din Europa, diagnosticul ultrasonografic se face în unități sanitare guvernamentale și private. Date fiind condițiile diferite, practica ecografică trebuie analizată atât în unitățile sanitare de stat, patronate în majoritatea cazurilor de către Ministerului Sănătății, cât și în cele din rețeaua privată.

Amintim că în ambele rețele (guvernamentală și privată) lucrează medici ecografiști absolvenți ai unei forme de învățământ ultrasonografic, care se desfășoară în unități acreditate de Ministerul Sănătății și de Ministerul Învățământului, după o programă unitară, propusă de Societatea Română de Ultrasonografie în Medicină și Biologie (SRUMB).

Capitala țării se situează în fruntea listei în ce privește numărul de unități sanitare guvernamentale și private în care se practică ultrasonografia pe nivele diferite de competență. Ultrasonografia este practicată de medici cu specialități diferite, atât de cei supraspecializați (ex: chirurgie vasculară, chirurgie pediatrică, etc), cât și de către medicii de familie.

Nivelul de competență a practicanților diagnosticului ultrasonografic este diferit și variază în funcție de vechimea în practica ultrasonografiei, de cursurile de perfecționare făcute în țară sau în străinătate, cât și de complexitatea sistemelor ultrasonografice aflate la dispoziție (module Doppler, de elastografie, programe de lucru cu substanțe de contrast, dispozitive pentru ecografie intervențională, etc).

În ultimii ani, prin implementarea sistemului de practicare a ultrasonografiei pe trei nivele de competență (nivelul Iîncepător, nivelul II- avansat, nivelul IIIexpert) promovat de SRUMB, un procent important dintre medicii ecografiști din București au devenit membrii ai Societății Naționale de Ultrasonografie și sunt în curs de aderare la acest sistem de practică în trepte.
Deși învățământul ultrasonografic este bine organizat după o programă unitară care respectă condițiile europene de practică, un punct slab îl constituie ofertainsuficientădecursuride perfecționare în unele domenii ale ultrasonografiei (ex: ecografia intervențională, lucrul cu substanțe de contrast, ecografia Doppler, etc).

Unele din aceste cursuri sunt organizate sub patronajul SRUMB sau al Societății Europene de Ultrasonografie (EFSUMB), de regulă, o dată pe an, cu ocazia Conferinței sau a Congresului Național al SRUMB, în orașul desemnat de organizatori, fiind poate din această cauză, mai greu accesibile. Un capitol interesant îl constituie contravaloarea investigațiilor ultrasonografice ce ar trebui achitată de pacient. Numărul mare de clinici de stat și private din București ar trebui să asigure o concurență reală și să garanteze accesul la diagnostice ecografice de înaltă acuratețe.

În rețeaua guvernamentală, prețul investigațiilor ecografice este suportat de către Casa de Asigurări de Sănătate (în marea majoritate a cazurilor). Aceasta rambursează contravaloarea investigațiilor ultrasonografice pentru unitățile sanitare (guvernamentale sau private) cu care are contracte. Din nefericire, Casa de Asigurări a subevaluat valoarea investigațiilor ecografice în urmă cu mai mulți ani și nu le-a reactualizat la nivelul real, până în prezent. Ori, pentru ca o metodă de diagnostic să fie eficientă, ea trebuie să fie corect finanțată pentru achiziția de aparatură modernă, asigurarea service-ului și a consumabilelor de calitate, lucru greu de asigurat în condițiile actuale.

În rețeaua privată, lucrurile stau mai bine din punctul de vedere al finanțării, costul investigațiilor ecografice fiind mult mai apropiat de cel real. Din păcate, organizarea în societăți cu răspundere limitată și funcționarea uneori pe criterii prea comerciale (ex: supraîncărcarea programului medicilor ecografiști cu scurtarea tim-

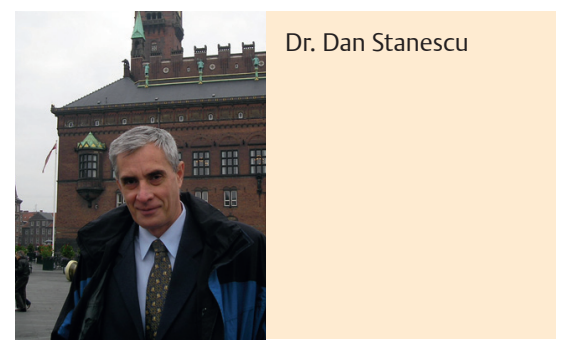

pului alocat investigației ultrasonografice), lipsa de interes a unora dintre managerii societăților private în pregătirea profesională a medicilor care practică ecografia, poate duce la scăderea calității investigațiilor.

În concluzie, în ciuda câtorva deficiențe semnalate, diagnosticul ecografic în București s-a îmbunătățit simțitor în ultimii ani. Infuzia de aparatură modernă, de sisteme ultrasonografice din clasa medieînaltă sau chiar din clasa high-end user (în rețeaua guvernamentală mai ales până la debutul crizei economice mondiale), în paralel cu creșterea numărului de medici specialiști din diferite domenii care practică ecografia, au permis transformarea ecografiei dintr-o metodă de selecție pentru alte metode de diagnostic imagistic, într-o metodă finală în diagnosticul multor afecțiuni. Încrederea medicilor terapeuți în diagnosticul ultrasonografic este în creștere și se materializează adesea în luarea unor decizii operatorii doar pe datele furnizate de investigația ecografică. Ultrasonografia beneficiază de aportul tehnic al unor module complementare (elastografie, echipamente 3D, programe de lucrul cu substanțe de contrast, echipamente sau transductori de eco-endoscopie, programe de fuziune de imagini, etc) care sporesc semnificativ capacitățile și încrederea în diagnosticul ultrasonografic.

Dan A. Stănescu - MD, PhD Șeful Departamentului de Medicină Nucleară și Ultrasonografie - Institutul Clinic Fundeni, București Membru fondator al SRUMB Instructor de Curs de Ultrasonografie Generală 
